\title{
Combating Antimicrobial Resistance Through Student-Driven Research and Environmental Surveillance
}

\author{
Erica R. Fuhrmeister ${ }^{1}$, Jennifer R. Larson ${ }^{2}$, Adam J. Kleinschmit ${ }^{3}$, James E. Kirby ${ }^{4}$, \\ Amy J. Pickering ${ }^{1}$ and Carol A. Bascom-Slack ${ }^{5 *}$
}

\begin{abstract}
'Department of Civil and Environmental Engineering, Tufts University School of Engineering, Medford, MA, United States, ${ }^{2}$ Department of Biological and Environmental Sciences, Capital University, Columbus, OH, United States, ${ }^{3}$ Department of Natural and Applied Sciences, University of Dubuque, Dubuque, IA, United States, ${ }^{4}$ Department of Pathology, Beth Israel Deaconess Medical Center, Boston, MA, United States, ${ }^{5}$ Department of Medical Education, Tufts University School of Medicine, Boston, MA, United States
\end{abstract}

OPEN ACCESS

Edited by: Davida Smyth,

The New School, United States

Reviewed by:

Dinesh Sriramulu,

Independent Researcher,

Chennai, India

Huiluo Cao,

The University of Hong Kong,

Hong Kong

*Correspondence:

Carol A. Bascom-Slack

carol.bascom_slack@tufts.edu

Specialty section: This article was submitted to Systems Microbiology,

a section of the journal

Frontiers in Microbiology

Received: 30 June 2020 Accepted: 14 January 2021 Published: 22 January 2021

Citation:

Fuhrmeister ER, Larson JR, Kleinschmit AJ, Kirby JE, Pickering AJ and

Bascom-Slack CA (2021) Combating Antimicrobial Resistance Through

Student-Driven Research and Environmental Surveillance.

Front. Microbiol. 12:577821. doi: 10.3389/fmicb.2021.577821
Emerging resistance to all classes of antimicrobials is one of the defining crises of the 21 st century. Many advances in modern medicine, such as routine surgeries, are predicated on sustaining patients with antimicrobials during a period when their immune systems alone cannot clear infection. The development of new antimicrobials has not kept pace with the antimicrobial resistance (AR) threat. AR bacteria have been documented in various environments, such as drinking and surface water, food, sewage, and soil, yet surveillance and sampling has largely been from infected patients. The prevalence and diversity of AR bacteria in the environment, and the risks they pose to humans are not well understood. There is consensus that environmental surveillance is an important first step in forecasting and targeting efforts to prevent spread and transmission of AR microbes. However, efforts to date have been limited. The Prevalence of Antibiotic Resistance in the Environment (PARE) is a classroom-based project that engages students around the globe in systematic environmental AR surveillance with the goal of identifying areas where prevalence is high. The format of PARE, designed as short classroom research modules, lowers common barriers for institutional participation in course-based research. PARE brings real-world microbiology into the classroom by educating students about the pressing public health issue of $A R$, while empowering them to be partners in the solution. In turn, the PARE project provides impactful data to inform our understanding of the spread of $A R$ in the environment through global real-time surveillance.

Keywords: antimicrobial resistance, antibiotic resistance, environmental surveillance, One Health, science education, citizen science, CURE (course-based undergraduate research experience)

\section{INTRODUCTION}

In October, 2020, the new United States National Action Plan for Combating AntibioticResistant Bacteria 2020-2025 was published (Federal Task Force on Combating AntibioticResistant Bacteria, 2020). This plan builds on the roadmap laid out in 2015, which takes a comprehensive approach to addressing the worldwide problem of antimicrobial resistance (AR). 
The approach is rooted in the concept of One Health, which recognizes that human health is inextricably linked to the environment, other animals, and plants (Zinsstag et al., 2011). Since then, coordinated progress has been made in several areas, yet one national goal with enormous untapped potential is that of strengthening national One Health surveillance efforts.

Surveillance of AR in the United States has focused mainly on food testing and epidemiological tracking of clinical infection (Lammie and Highes, 2016). Clinicians and epidemiologists respond primarily to existing threats. Patients present with a resistant infection before epidemiologists are invoked to trace the source and contain the spread. Epidemiological tracking of infectious disease can contain transmission and food testing is a proactive, preventative measure, but more must be done to prevent infections before they arise. As a result of the SARSCoV-2 pandemic, there is increased awareness of the need to study microbes and transmission patterns in non-clinical settings (i.e., the environment) to prevent the emergence of infectious disease outbreaks.

Antibiotics discharged into the environment provide a selective pressure for survival of microbes harboring AR. Waste streams from livestock, hospitals, households, and industry production of antibiotics can contribute to dissemination of antibiotics and $\mathrm{AR}$ into the environment, and AR bacteria and AR genes have been documented in numerous environmental reservoirs (e.g., Aarestrup et al., 1998; Nwosu, 2001; Schwartz et al., 2003; D'Costa et al., 2006; Salyers and Shoemaker, 2006; Lobova et al., 2008; Allen et al., 2010; Institute of Medicine (US) Forum on Microbial Threats, 2010; Wright, 2010; Berglund, 2015; Li et al., 2015). Robust environmental surveillance of water and soil samples has the potential to identify hotspots of AR, which could lead to localized stewardship efforts to contain spread of resistance, possibly preventing AR outbreaks.

Environmental scientists generally conduct in-depth studies to monitor presence and/or abundance of AR genes or levels of culturable AR bacteria in environmental samples from a limited geographic range, but we argue that a more proactive and coordinated approach among clinicians, epidemiologists, and environmental scientists must be taken. For example, there remains a disconnect between the resistance genes surveyed in the environment and those deemed clinically relevant by medical practitioners. Even among scientists, groups rarely use the same sampling schemes, methods, or reporting metrics, making comparisons across studies challenging. We propose that this gap can be addressed, in part, by undergraduates as citizen scientists conducting environmental surveillance to identify environmental hotspots of AR, with findings made available in a database. At the same time, engaging undergraduates in a large research study has the potential to fill an unmet need in undergraduate education - providing more access to authentic research experiences.

Despite the environmental presence of AR bacteria and widespread use of antimicrobials, the public is generally unaware of environmental resistance as a global public health problem (McCullough et al., 2016; Wellcome Trust, 2019). This is compounded by lack of understanding regarding natural selection and how presence of antibiotics leads to selection for AR bacteria.
Reduction in use of antimicrobials in agriculture, aquaculture, veterinary, and human medicine are all critical to decrease selective pressure for survival and spread of resistant microbes. One notable example of the power of the informed public is the increase in consumer demand for meat production without antibiotics, which has driven food chains to seek out sources of animals treated with fewer or no antibiotics (Neilsen FreshFacts, 2016; Halloran and Bohne, 2017; Singer et al., 2019). This is significant because interventions that restrict antibiotic use in food animals are tightly associated with a decrease in AR bacteria in these animals (Tang et al., 2017). Collectively, an educated public and the resulting behavioral changes have the power to impact the issue of $\mathrm{AR}$ through reducing unnecessary use of antimicrobials.

Currently there is a need for consistent messaging that engages citizens in antibiotic stewardship. Educating the public about the growing AR crisis has been identified in the President's Council of Advisors on Science and Technology (PCAST) Report on Combating Antibiotic Resistance as a critical factor for improving antimicrobial stewardship, especially regarding the demand for inappropriate antimicrobial prescriptions (Olson and Riordan, 2012). In addition, many organizations including the [World Health Organization (WHO), 2015], the Wellcome Trust (2019), and the Centers for Disease Control and Prevention (Federal Task Force on Combating Antibiotic-Resistant Bacteria, 2020) have stated that educating the general public is a critical component in the battle against AR. We argue that the classroom is an ideal environment, that of a captive audience, in which to convey consistent, but simple messaging regarding the issue of $\mathrm{AR}$ and actions that can be taken by individuals.

\section{COURSE-BASED RESEARCH EXPERIENCES: IMPROVED PEDAGOGY AND INCREASED SCIENTIFIC POTENTIAL}

The last 70 years have brought a revolutionary shift in the way we approach teaching laboratory courses. Inquiry-based learning aims to move from the traditional memorization of facts to a process that allows students to "discover" scientific principles through their own experimentation (National Research Council, 1996, 2000; Chiappetta, 2007). Course-based undergraduate research experiences (CUREs) could be considered the next generation of inquiry-based learning. In contrast to inquiry-based instruction, in which the results are generally of limited interest to the broader scientific community, CUREs provide an opportunity for students (typically undergraduates) to collect and analyze data that have potential to lead to new scientific findings of interest beyond the classroom (Lopatto, 2003; Hatfull et al., 2006; Buck et al., 2008; Kloser et al., 2011; Fukami, 2013; Alaimo et al., 2014; Auchincloss et al., 2014; Spell et al., 2014; National Academies of Sciences, Engineering, and Medicine, 2015; Weaver et al., 2020) and are an attempt to scale up the traditional apprentice-style research experiences for undergraduates (Wei and Woodin, 2011; 
Olson and Riordan, 2012; National Academies of Sciences, Engineering, and Medicine, 2015). Placing the research experience in the context of a classroom provides opportunities for students who may not otherwise have access to research, such as those attending community colleges or who cannot afford to engage in an unpaid, out-of-class program or internship (Bangera and Brownell, 2014; Hensel and Davidson, 2018).

There is growing recognition that authentic research experiences are valuable to promote desired outcomes in early STEM education, especially retention, improvement in academic achievement, and matriculation into graduate and professional programs. Recently, there has been an explosion in interest in and development of CUREs (e.g., American Association for the Advancement of Science, 2011; Wei and Woodin, 2011; Olson and Riordan, 2012; National Academies of Sciences, Engineering, and Medicine, 2015). In addition to the valuable potential of CUREs to engage and retain STEM students, CUREs have proven effective tools to engage students in tackling scientific challenges that are not well suited to an individual research group, but instead require a large cohort to work en masse.

A key aspect to many successful CUREs is the power of contributing to a collective data set that is available to the larger research community (Hatfull et al., 2006; Shaffer et al., 2010; Jordan et al., 2014; Wiley and Stover, 2014; Leung et al., 2015). Programs with early success in crowd-sourcing studentgenerated data to tackle big research questions have provided inspiration for scientists in other fields to consider harnessing the power of undergraduates in the classroom to advance science (Elgin et al., 2016, 2017). Students participating in course-based research have contributed to scientific knowledge both through peer-reviewed publications and contributions to databases (e.g., Jordan et al., 2014; Leung et al., 2015; Elgin et al., 2017). The power of student-generated discoveries has been further solidified with the recent publication describing treatment of a cystic fibrosis patient with a combination of engineered, student-derived bacteriophages that killed an infectious strain of Mycobacterium abscessus (Dedrick et al., 2019).

\section{THE PREVALENCE OF ANTIBIOTIC RESISTANCE IN THE ENVIRONMENT: A CLASSROOM-BASED ENVIRONMENTAL SURVEILLANCE PROJECT}

The Prevalence of Antibiotic Resistance in the Environment (PARE) project is a powerful platform for student learning and scientific discovery that has potential to address the scientific challenges associated with environmental surveillance of AR and to educate tomorrow's decision makers about the public health threat of AR and the biological concept of natural selection. The PARE project is a CURE in which standardized student crowdsourcing data are used to generate a Geographic Information Systems (GIS)-based map of AR data (Figures 1A,B). The overarching scientific goal is to identify environmental hotspots of AR that could present risk for human exposure and infection. The educational goal is to make research more equitable for students by creating a scalable, sustainable

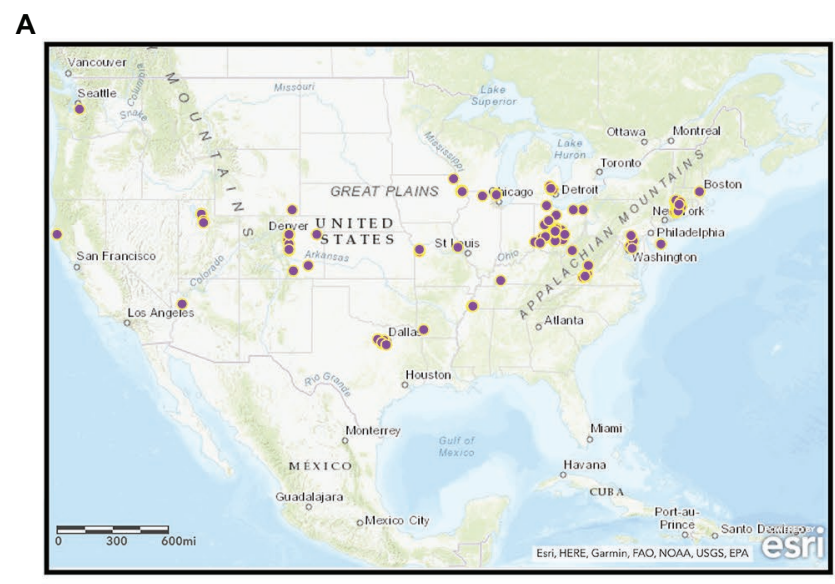

B

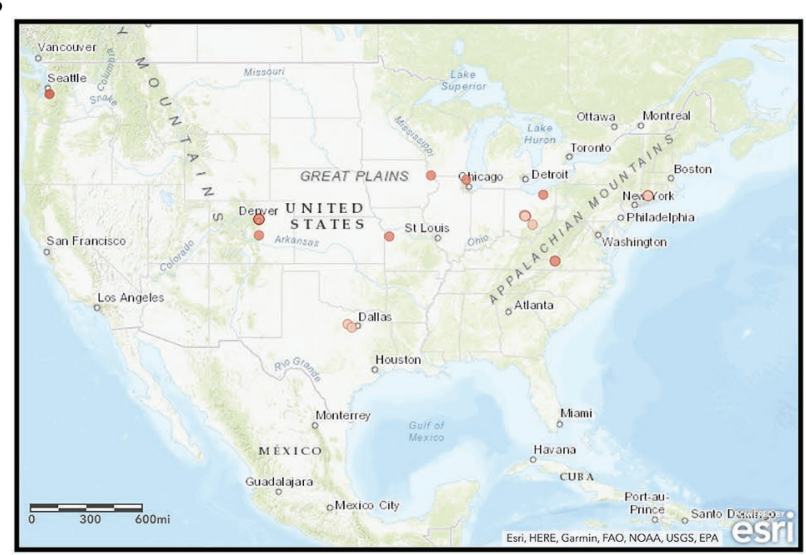

C
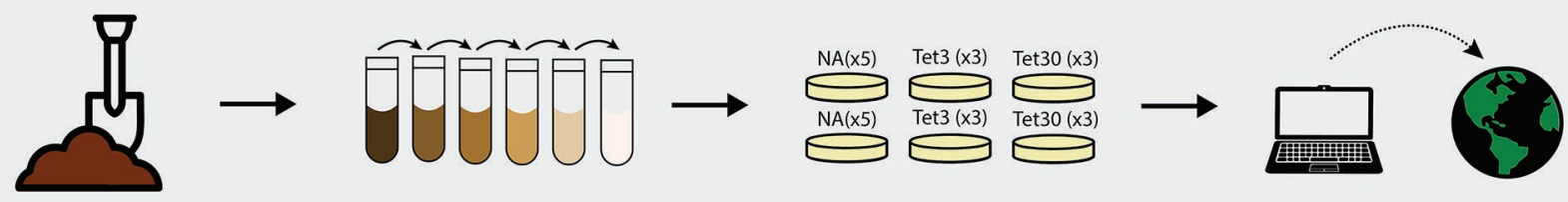

FIGURE 1 | Prevalence of Antibiotic Resistance in the Environment (PARE) Project. The geographic information systems (GIS)-based maps depicting student soil sample collection sites (A), and samples harboring culturable bacteria resistant to $30 \mu \mathrm{g} / \mathrm{ml}$ tetracycline (B). Dark red dots represent samples in which greater than $25 \%$ of colony forming units were resistant; light red dots represent less than $25 \%$ resistance. (C) Outlines the methods used by students to obtain the data shown in the maps. Detailed description of methods available in Genné-Bacon and Bascom-Slack (2018). 
research program that can be carried out in classrooms at the undergraduate level, while extending across institution types.

The reach of PARE transcends traditional cohorts of undergraduate biology majors as the curriculum is uniquely situated to engage heterogeneous groups of students beyond the microbiology classroom including non-biology majors and high school students. PARE provides a captivating context for teaching a wide array of core interconnected biological principles (e.g., natural selection, adaptation, mutagenesis, and cell structure/ function), while addressing the contemporary public health issue of AR. Students experience and learn about the process of science through the design and execution of experiments, and through grappling with the messiness inherent in authentic experimental data.

In the original, core PARE module (Genné-Bacon and Bascom-Slack, 2018) students collect soil, perform serial dilutions, and plate onto media with or without defined concentrations of tetracycline (Figure 1C). Tetracycline was selected for this surveillance project, in part, because it is inexpensive, easy to use and it has a long history of use and study in agriculture (Daghrir and Drogui, 2013; Zhou et al., 2017). Students analyze growth on plates, then calculate and upload the prevalence of tetracycline-resistant colony forming units into a database. Once students upload their PARE results, their prevalence data appears instantly with their soil collection site on an interactive, web-based map. Feedback from participating faculty indicates that a motivator for participating in PARE is the knowledge that students are part of a research community, contributing to a larger body of knowledge (Genné-Bacon et al., 2020).

\section{DATA CURATION}

Curation of student-generated data has been a challenge; yet, we have created a new data upload and display system to address many issues that became apparent after the first few years of data collection. Our current system allows display of all soil data collection sites, but blocks display of tetracycline resistance data that do not meet curation criteria. This new GIS-based system was introduced just prior to the onset of the COVID-19 pandemic in which most instructors had to abort their in-person teaching. Nonetheless, this fall, nearly 300 student entries have been recorded. Students upload global positioning system (GPS) metadata captured from a smartphone at the time and place of their sample collection. This eliminates a previous problem of inaccurate location information. Another common observed problem is errors in calculations. For determination of prevalence data, students must count colonies that grow on media with and without tetracycline, and then perform calculations to determine the percent of colonies that are resistant. Analyses of earlier datasets indicated that about $1 / 3$ of entries contained calculation errors. Error types included incorrect use of scientific notation, (e.g., incorrect by an order of magnitude), simple arithmetic errors (e.g., failure to account for dilution factors), and missing data. In our current automated curation, prompts are designed to eliminate scientific notation errors and each step that requires a calculation is calculated automatically based on student colony counts entered. If the computer-generated value does not equal student-generated value, a warning message appears notifying the student and providing opportunity for them to re-check their entries and calculations. Our curation standard for tetracycline resistance data display also requires entry of two duplicate plate sets from the same soil sample. These duplicate counts must not be more than $50 \%$ different. These measures have solved many previous problems with the data quality. We cannot, however, verify that students perform accurate colony counts, although two students are instructed to first independently count then compare and arrive at consensus. In addition, depending on the local environment, some dilution sets are simply not countable due to contamination, overgrowth, or undergrowth. To date, of 294 entries, 20\% pass our curation standard. While this number is low, we believe, we can reach significant numbers because the growing network of participants implementing PARE includes thousands of students at over 120 undergraduate institutions, approximately 20 high schools, and international partners in France, India, and Botswana. We believe this "first pass" of surveillance complements the rigorous in-depth, but geographicallylimited studies being conducted by environmental scientists.

\section{DATA ANALYSIS}

Students are asked to form a hypothesis about expected levels of $\mathrm{AR}$ in their samples based on collection site characteristics. After resulting AR frequencies are calculated, students first enter data into a shared cloud-based spreadsheet that provides an opportunity to view the classroom data, and to identify and correct errors before database upload. A curated, comprehensive spreadsheet of data is also available on our website for instructors who prefer to have their students work with a larger dataset. In analyses of the data, students are confronted with the messiness of real biological data, which serves as an important learning opportunity and puts them in the shoes of scientists. Students have reported that this reflection helps reinforce the importance of careful attention to methods. Upon reflecting on classroom results, students are asked whether they are consistent with predictions and engage in discussion of potential explanations. Simple analytical activities include determining how best to represent the classroom data and use of $t$-tests to compare average resistance levels at different sites, both of which help build quantitative skills. Some instructors also require students to produce a scientific poster or oral presentation of their results. The student GIS-based database provides enormous potential for data visualization and analysis. Student data can be mapped and analyzed in relation to existing GIS datasets such as land use patterns, pollution/emissions monitoring, and health tracking. A future goal is to augment the curriculum with instructions for students to carry out these analyses.

\section{PARE IS A FLEXIBLE AND INCLUSIVE WAY TO ENGAGE DIVERSE STUDENTS}

Approximately one-third of PARE-participating institutions are community colleges. This is notable because there are 
known barriers associated with faculty development and implementation of CUREs (Spell et al., 2014; Harris et al., 2015; Shortlidge et al., 2016; Craig, 2017), and data suggest that these tend to be particularly significant for faculty at community colleges (Spell et al., 2014). One way in which
PARE lowers barriers for implementation is through its modular design. Since its inception, PARE has partnered with instructors, faculty

experts, and industry to design a suite of classroom research modules, complementary to the core module (Table 1).

TABLE 1 | PARE project laboratory module descriptions.

\begin{tabular}{|c|c|c|c|}
\hline Module name and type & Description & Major skills embedded & Difficulty \\
\hline Data analysis case study (Online possible) & $\begin{array}{l}\text { A classroom exercise created with the } \\
\text { Great Diseases project, guiding students } \\
\text { through a simplified version of a seminal } \\
\text { report investigating the outcome of } \\
\text { introducing tetracycline use on farms } \\
\text { (Jacque et al., 2013). }\end{array}$ & Data analysis & Introductory level \\
\hline Molecular case study & $\begin{array}{l}\text { A known-outcome case study narrative, } \\
\text { created in collaboration with miniPCR }{ }^{\mathrm{TM}} \\
\text { (https://www.minipcr.com), in which } \\
\text { students employ PCR to trace the } \\
\text { source of a simulated antimicrobial } \\
\text { resistance (AR) outbreak. }\end{array}$ & $\begin{array}{l}\text { PCR } \\
\text { Gel electrophoresis }\end{array}$ & Introductory level \\
\hline Core module & $\begin{array}{l}\text { A culture-based exercise in which soil } \\
\text { samples are diluted and plated onto } \\
\text { media with and without tetracycline to } \\
\text { determine relative prevalence of AR } \\
\text { microbes (152). }\end{array}$ & $\begin{array}{l}\text { Serial dilution } \\
\text { Plating } \\
\text { CFU determination }\end{array}$ & Introductory or upper level \\
\hline Virtual colony count (Online possible) & $\begin{array}{l}\text { An online activity to simulate the Core } \\
\text { PARE module. }\end{array}$ & CFU determination & Introductory or upper level \\
\hline Identification of $T C^{R}$ genes & $\begin{array}{l}\text { A non-culture-based activity in which soil } \\
\text { DNA is extracted and tested for the } \\
\text { presence of two common tetracycline- } \\
\text { resistance genes, tetM and tetA using } \\
\text { PCR [created in collaboration with } \\
\text { miniPCR }^{\mathrm{TM}} \text { ]. }\end{array}$ & $\begin{array}{l}\text { DNA extraction } \\
\text { PCR } \\
\text { Gel electrophoresis }\end{array}$ & Introductory or upper level \\
\hline Colony identification & $\begin{array}{l}16 \mathrm{~S} \text { rRNA gene sequence analysis is } \\
\text { performed on DNA extracted from } \\
\text { tetracycline-resistant colonies (isolated in } \\
\text { the core module) to make a preliminary } \\
\text { phylogenetic assignment. }\end{array}$ & $\begin{array}{l}\text { DNA extraction } \\
\text { PCR } \\
\text { Gel electrophoresis } \\
\text { BLAST search } \\
\text { Sequence analysis }\end{array}$ & Introductory or upper level \\
\hline Multi-drug resistance testing & $\begin{array}{l}\text { Colonies isolated in the core PARE } \\
\text { module are tested for resistance to other } \\
\text { antimicrobials using a Kirby-Bauer } \\
\text { assay. }\end{array}$ & $\begin{array}{l}\text { Culturing } \\
\text { Kirby-Bauer testing }\end{array}$ & Introductory or upper level \\
\hline $\begin{array}{l}\text { Identification of clinically important } \\
\text { resistance genes (in development) }\end{array}$ & $\begin{array}{l}\text { Soil DNA is extracted and tested for the } \\
\text { presence of emergent resistance gene } \\
\text { markers (e.g., bla } \text { NDM1 }_{\text {and } m c r 1) \text {. }}\end{array}$ & $\begin{array}{l}\text { DNA extraction } \\
\text { PCR } \\
\text { Gel electrophoresis }\end{array}$ & Introductory or upper level \\
\hline Bioinformatics 1 (Online possible) & $\begin{array}{l}\text { A computer-based sequence analysis } \\
\text { activity comparing tetracycline-resistance } \\
\text { genes from different bacterial species. }\end{array}$ & $\begin{array}{l}\text { Sequence analysis } \\
\text { BLAST search }\end{array}$ & Introductory or upper level \\
\hline Bioinformatics 2 (Online) & $\begin{array}{l}\text { Using on online bioinformatics workflow } \\
\text { to search metagenomic soil and water } \\
\text { DNA sequence for antibiotic resistance } \\
\text { genes. }\end{array}$ & $\begin{array}{l}\text { Interpretation and analysis of } \\
\text { bioinformatics data }\end{array}$ & Upper level \\
\hline Horizontal transfer & $\begin{array}{l}\text { Tests for the ability of the resistance } \\
\text { determinant to transfer via horizontal } \\
\text { gene transfer. }\end{array}$ & $\begin{array}{l}\text { Plasmid extraction } \\
\text { Bacterial transformation } \\
\text { Plating }\end{array}$ & Upper level \\
\hline
\end{tabular}

Modules are generally organized from least to most challenging in terms of technical skills and/or content. There is no specific order in which the modules must be completed. $C F U$, colony forming units; $T C^{R}$, tetracycline resistance; $A R$, antimicrobial resistant. 
The modules integrate a variety of methods (culture-based and molecular) to assay environmental samples for indications of AR bacteria or associated molecular markers. Table 1 lists the modules in order of general progression in terms of technical difficulty, time, and reagents required; however, there is no set order in which the modules must be introduced. This flexibility draws instructors from a wide variety of courses and institution types, many of whom have never introduced authentic research into their laboratory courses before. The modular nature of PARE reduces faculty perceived barriers to adopting CUREs by providing faculty with the ability to transition from a traditional laboratory curriculum to a CURE by progressively adding subsequent research modules (GennéBacon et al., 2020). It has been documented that, for students, the benefits gained from CUREs increase with time spent immersed within the research project (Shaffer et al., 2014), so it is notable that the majority of PARE instructors transition from implementation of the core module to an expanded experience by their second year of implementation (unpublished results). PARE is continuing to expand its scientific impact through development of additional modules to assess presence of clinically relevant $\mathrm{AR}$ genes such as $b l a_{\mathrm{NDM} 1}, m c r 1$, and ribosomal methylase-mediated aminoglycoside resistance. Future plans include proactively seeking to detect resistance to newly marketed antimicrobials and those with promise in development.

Many science departments are currently working to integrate a scaffolded CURE experience into the curriculum for undergraduates by offering a progression in which skills or concepts learned in an introductory-level CURE are built upon in a later, upper-level CURE. PARE provides an opportunity for scaffolding of different modules in different courses. In addition, it is complementary to other nationally-disseminated semester-long CUREs such as Tiny Earth/Small World Initiative (Barral et al., 2014, 2016; Hurley et al., 2020), SEA PHAGES (Hatfull et al., 2006; Jordan et al., 2014), and Authentic Research Experience in Microbiology (Muth and McEntee, 2014; Muth and Caplan, 2020). All are focused on some aspect of environmental microbiology, so together they provide readyto-use options for scaffolding. Tiny Earth provides a particularly appealing complement to PARE due to its focus on discovery of antibiotic-producing microbes from soil samples.

\section{DISCUSSION}

A lack of systematic contributions by governmental agencies, non-profits, and research laboratories has left a knowledge deficit that provides an ideal opportunity for PARE to educate students on the problem of environmental resistance and engage

\section{REFERENCES}

Aarestrup, F. M., Bager, F., Jensen, N. E., Madsen, M., Meyling, A., and Wegener, H. C. (1998). Surveillance of antimicrobial resistance in bacteria isolated from food animals to antimicrobial growth promoters and related therapeutic agents in Denmark. APMIS 106, 606-622. doi: 10.1111/ j.1699-0463.1998.tb01391.x them in a research experience with potential for meaningful scientific and societal impact. By engaging a broad constituency of students, including those who will funnel into the healthcare workforce as well as non-STEM sectors of society, PARE directly addresses the need for effective, widely-disseminated messaging to explain the One Health nature of AR and does so in a tangible, personally compelling manner. In addition, the establishment of a standardized environmental surveillance system has the potential to identify hotspots of AR, identify human exposure pathways, monitor for emerging resistant pathogens, and generate data for educational programs to increase public awareness. Increasing understanding of the distribution of AR in their own community not only provides a powerful hook to engage students but also provides an opportunity to enlist them as research partners in a project with broad scientific merit. Students who participate in PARE will further serve as future ambassadors within and outside of healthcare environments, disseminating the critical message that $\mathrm{AR}$ is a threat that everyone should not only care about, but one in which they can directly participate in the solution by improving their antimicrobial stewardship.

\section{AUTHOR CONTRIBUTIONS}

CB-S wrote the majority of the manuscript with contributions on the environmental perspective from $\mathrm{EF}$ and $\mathrm{AP}$ and on the clinical perspective from $\mathrm{JK}$, and performed the literature search. JL and AK contributed to sections on the Prevalence of Antibiotic Resistance in the Environment Project and public perceptions. EF created the figure. All authors contributed to the article and approved the submitted version.

\section{FUNDING}

This article is based upon work supported by the NSF Postdoctoral Research Fellowships in Biology Program under Grant No. 1906957 to EF and NSF IUSE Grant No. 1640399 to $\mathrm{CB}-\mathrm{S}$.

\section{ACKNOWLEDGMENTS}

We would like to thank EmilyKate McDonough who contributed the Figure 1 and Scarlet Bliss who has been instrumental in developing and evaluating new curriculum. Sebastian Kraves, Bruce Bryon, Brad Goodner, and Joy Coughron have all contributed to curriculum noted in Table 1. 
American Association for the Advancement of Science (2011). Vision and change in undergraduate biology education: A call to action. Washington, DC: AAAS.

Auchincloss, L. C., Laursen, S. L., Branchaw, J. L., Eagan, K., Graham, M., Hanauer, D. I., et al. (2014). Assessment of course-based undergraduate research experiences: a meeting report. CBE Life Sci. Educ. 13, 29-40. doi: 10.1187/cbe.14-01-0004

Bangera, G., and Brownell, S. E. (2014). Course-based undergraduate research experiences can make scientific research more inclusive. CBE Life Sci. Educ. 13, 602-606. doi: 10.1187/cbe.14-06-0099

Barral, A. M., Makhluf, H., Broderick, N. A., and Kurt, E. L. (2016). The small world initiative $\mathrm{T}^{\mathrm{TM}}$ : an innovative crowdsourcing platform for antibiotics. FASEB J. 30:665.13. doi: 10.1096/fasebj.30.1_supplement.665.13

Barral, A. M., Makhluf, H., Soneral, P., and Gasper, B. (2014). Small world initiative: crowdsourcing research of new antibiotics to enhance undergraduate biology teaching. FASEB J. 28:618.41. doi: 10.1096/fasebj.28.1_supplement.618.41

Berglund, B. (2015). Environmental dissemination of antibiotic resistance genes and correlation to anthropogenic contamination with antibiotics. Infect. Ecol. Epidemiol. 5:28564. doi: 10.3402/iee.v5.28564

Buck, L. B., Bretz, S. L., and Towns, M. (2008). Characterizing the level of inquiry in the undergraduate laboratory. J. Coll. Sci. Teach. 38, 52-58.

Chiappetta, E. L. (2007). Science as inquiry in the secondary setting. eds. J. Luft, L. B. Randy and J. Gess-Newsome (Arlington, VA: National Science Teaching Association).

Craig, P. A. (2017). A survey on faculty perspectives on the transition to a biochemistry course-based undergraduate research experience laboratory. Biochem. Mol. Biol. Educ. 45, 426-436. doi: 10.1002/bmb.21060

Daghrir, R., and Drogui, P. (2013). Tetracycline antibiotics in the environment: a review. Environ. Chem. Lett. 11, 209-227. doi: 10.1007/s10311-013-0404-8

D'Costa, V. M., McGrann, K. M., Hughes, D. W., and Wright, G. D. (2006). Sampling the antibiotic resistome. Science 311, 374-377. doi: 10.1126/ science. 1120800

Dedrick, R. M., Guerrero-Bustamante, C. A., Garlena, R. A., Russell, D. A., Ford, K., Harris, K., et al. (2019). Engineered bacteriophages for treatment of a patient with a disseminated drug-resistant mycobacterium abscessus. Nat. Med. 25, 730-733. doi: 10.1038/s41591-019-0437-z

Elgin, S. C. R., Bangera, G., Decatur, S. M., Dolan, E. L., Guertin, L., Newstetter, W. C., et al. (2016). Insights from a convocation: integrating discovery-based research into the undergraduate curriculum. CBE Life Sci. Educ. 15:fe2. doi: 10.1187/cbe.16-03-0118

Elgin, S. C. R., Hauser, C., Holzen, T. M., Jones, C., Kleinschmit, A., Leatherman, J., et al. (2017). The GEP: crowd-sourcing big data analysis with undergraduates. Trends Genet. 33, 81-85. doi: 10.1016/j.tig.2016.11.004

Federal Task Force on Combating Antibiotic-Resistant Bacteria (2020). National action plan for combatting antibiotic-resistant bacteria 2020-2025.

Fukami, T. (2013). IBI* series winner. Integrating inquiry-based teaching with faculty research. Science 339, 1536-1537. doi: 10.1126/science.1229850

Genné-Bacon, E. A., and Bascom-Slack, C. A. (2018). The PARE project: a short course-based research project for national surveillance of antibioticresistant microbes in environmental samples. J. Microbiol. Biol. Educ. 19:19.3.97. doi: 10.1128/jmbe.v19i3.1603

Genné-Bacon, E. A., Wilks, J., and Bascom-Slack, C. (2020). Uncovering factors influencing instructors' decision process when considering implementation of a course-based research experience. CBE Life Sci. Educ. 19:ar13. doi: 10.1187/cbe.19-10-0208

Halloran, J., and Bohne, M. (2017). Chain reaction III: how top restaurants rate on reducing use of antibiotics in their meat supply. Available at: https:// advocacy.consumerreports.org/wp-content/uploads/2017/09/ChainReaction3_ Report_final.pdf

Harris, A., Babkoor, M., Gu, T., and Kremer, G. E. (2015). "Course-Based Undergraduate Research: A Review of Models and Practices." in ASME 2015 International design engineering technical conferences and computers and information in engineering conference; August 2-5, 2015; Boston, MA.

Hatfull, G. F., Pedulla, M. L., Jacobs-Sera, D., Cichon, P. M., Foley, A., Ford, M. E., et al. (2006). Exploring the mycobacteriophage metaproteome: phage genomics as an educational platform. PLoS Genet. 2:e92. doi: 10.1371/journal.pgen. 0020092

Hensel, N. H., and Davidson, C. N. (2018). Course-based undergraduate research: Educational equity and high-impact practice. ed. N. H. Hensel (Washington, DC: Council for Undergraduate Research and Stylus Publishing).
Hurley, A., Chevrette, M. G., Acharya, D. D., Lozano, G. L., Garavito, M., Heinritz, J., et al. (2020). Tiny earth: a big idea for STEM education and antibiotic discovery [Preprint]. CBE Life Sci. Educ. doi: 10.20944/ preprints202011.0250.v1

Institute of Medicine (US) Forum on Microbial Threats (2010). Antibiotic resistance: Implications for global health and novel intervention strategies. Washington, DC: National Academies Press.

Jacque, B., Malanson, K., Bateman, K., Akeson, B., Cail, A., Doss, C., et al. (2013). The great diseases project: a partnership between tufts medical school and the boston public schools. Acad. Med. 88, 620-625. doi: 10.1097/ ACM.0b013e31828b50fb

Jordan, T. C., Burnett, S. H., Carson, S., Caruso, S. M., Clase, K., DeJong, R. J., et al. (2014). A broadly implementable research course in phage discovery and genomics for first-year undergraduate students. mBio 5, e01051-e01113. doi: $10.1128 / \mathrm{mBio} .01051-13$

Kloser, M. J., Brownell, S. E., Chiariello, N. R., and Fukami, T. (2011). Integrating teaching and research in undergraduate biology laboratory education. PLoS Biol. 9:e1001174. doi: 10.1371/journal.pbio.1001174

Lammie, S. L., and Highes, J. M. (2016). Antimicrobial resistance, food safety, and one health: the need for convergence. Annu. Rev. Food Sci. Techol. 7, 287-312. doi: 10.1146/annurev-food-041715-033251

Leung, W., Shaffer, C. D., Reed, L. K., Smith, S. T., Barshop, W., Dirkes, W., et al. (2015). Drosophila muller f elements maintain a distinct set of genomic properties over 40 million years of evolution. G3 5, 719-740. doi: 10.1534/ g3.114.015966

Li, B., Yang, Y., Ma, L., Ju, F., Guo, F., Tiedje, J. M., et al. (2015). Metagenomic and network analysis reveal wide distribution and co-occurrence of environmental antibiotic resistance genes. ISME J. 9, 2490-2502. doi: 10.1038/ismej.2015.59

Lobova, T. I., Barkhatov, Y. V., Salamatina, O. V., and Popova, L. Y. (2008). Multiple antibiotic resistance of heterotrophic bacteria in the littoral zone of lake shira as an indicator of human impact on the ecosystem. Microbiol. Res. 163, 152-160. doi: 10.1016/j.micres.2006.03.014

Lopatto, D. (2003). The essential features of undergraduate research. Counc. Undergrad. Res. Q. 24, 139-142.

McCullough, A. R., Parekh, S., Rathbone, J., Del Mar, C. B., and Hoffmann, T. C. (2016). A systematic review of the public's knowledge and beliefs about antibiotic resistance. J. Antimicrob. Chemother. 71, 27-33. doi: 10.1093/jac/dkv310

Muth, T. R., and Caplan, A. J. (2020). Microbiomes for All. Front. Microbiol. 11:593472. doi: $10.3389 /$ fmicb. 2020.593472

Muth, T. R., and McEntee, C. M. (2014). Undergraduate urban metagenomics research module. J. Microbiol. Biol. Edu. 15, 38-40. doi: 10.1128/jmbe.v15i1.645

National Academies of Sciences, Engineering, and Medicine (2015). Integrating discovery-based research into the undergraduate curriculum: Report of a convocation. Washington, DC: National Academies Press.

National Research Council (1996). National science education standards. Washington, DC: National Academies Press.

National Research Council (2000). Inquiry and the national science education standards: A guide for teaching and learning. Washington, DC: The National Academies Press.

Neilsen FreshFacts (2016). Weighing consumers' growing appetite for "clean" meat labeling. Available at: https:/www.nielsen.com/us/en/insights/article/2016/ weighing-consumers-growing-appetite-for-clean-meat-labeling/ (Accessed May $18,2020)$.

Nwosu, V. C. (2001). Antibiotic resistance with particular reference to soil microorganisms. Res. Microbiol. 152, 421-430. doi: 10.1016/s0923-2508(01)01215-3

Olson, S., and Riordan, D. G. (2012). "Engage to excel: producing one million additional college graduates with degrees in science, technology, engineering, and mathematics. Report to the President." Executive Office of the President: 130. Available at: http://files.eric.ed.gov/fulltext/ED541511.pdf

Salyers, A., and Shoemaker, N. B. (2006). Reservoirs of antibiotic resistance genes. Anim. Biotechnol. 17, 137-146. doi: 10.1080/10495390600957076

Schwartz, T., Kohnen, W., Jansen, B., and Obst, U. (2003). Detection of antibioticresistant bacteria and their resistance genes in wastewater, surface water, and drinking water biofilms. FEMS Microbiol. Ecol. 43, 325-335. doi: 10.1111/j.1574-6941.2003.tb01073.x

Shaffer, C. D., Alvarez, C., Bailey, C., Barnard, D., Bhalla, S., Chandrasekaran, C., et al. (2010). The genomics education partnership: successful integration of research into laboratory classes at a diverse group of undergraduate institutions. CBE Life Sci. Educ. 9, 55-69. doi: 10.1187/09-11-0087 
Shaffer, C. D., Alvarez, C. J., Bednarski, A. E., Dunbar, D., Goodman, A. L., Reinke, C., et al. (2014). A course-based research experience: how benefits change with increased investment in instructional time. CBE Life Sci. Educ. 13, 111-130. doi: 10.1187/cbe-13-08-0152

Shortlidge, E. E., Bangera, G., and Brownell, S. E. (2016). Faculty perspectives on developing and teaching course-based undergraduate research experiences. Bioscience 66, 54-62. doi: 10.1093/biosci/biv167

Singer, R. S., Porter, L. J., Thomson, D. U., Gage, M., Beaudoin, A., and Wishnie, J. K. (2019). Raising animals without antibiotics: U.S. producer and veterinarian experiences and opinions. Front. Vet. Sci. 6:452. doi: 10.3389/ fvets. 2019.00452

Spell, R. M., Guinan, J. A., Miller, K. R., and Beck, C. W. (2014). Redefining authentic research experiences in introductory biology laboratories and barriers to their implementation. CBE Life Sci. Educ. 13, 102-110. doi: 10.1187/cbe.13-08-0169

Tang, K. L., Caffrey, N. P., Nóbrega, D. B., Cork, S. C., Ronksley, P. E., Barkema, H. W., et al. (2017). Restricting the use of antibiotics in foodproducing animals and its associations with antibiotic resistance in foodproducing animals and human beings: a systematic review and meta-analysis. Lancet Planet. Health 1, e316-e327. doi: 10.1016/S2542-5196(17)30141-9

Weaver, G. C., Russell, C. B., and Wink, D. J. (2020). Inquiry-based and research-based laboratory pedagogies in undergraduate science. Nat. Chem. Biol. 4, 577-580. doi: 10.1038/nchembio1008-577

Wei, C. A., and Woodin, T. (2011). Undergraduate research experiences in biology: alternatives to the apprenticeship model. CBE Life Sci. Educ. 10, 23-31. doi: 10.1187/cbe.11-03-0028

Wellcome Trust (2019). Reframing Resistance 2019. Available at: https://wellcome. ac.uk/reports/reframing-antimicrobial-resistance-antibiotic-resistance (Accessed May 18, 2020).

Wiley, E. A., and Stover, N. A. (2014). Immediate dissemination of student discoveries to a model organism database enhances classroom-based research experiences. CBE Life Sci. Educ. 13, 131-138. doi: 10.1187/ cbe.13-07-0140

World Health Organization (WHO) (2015). Global action plan on antimicrobial resistance. 2017-04-11 12:45:48 2015. Available at: https://www.who.int/ antimicrobial-resistance/publications/global-action-plan/en/ (Accessed May 18, 2020).

Wright, G. D. (2010). Antibiotic resistance in the environment: a link to the clinic? Curr. Opin. Microbiol. 13, 589-594. doi: 10.1016/j.mib.2010.08.005

Zhou, Y., Niu, L., Zhu, S., Lu, H., and Liu, W. (2017). Occurrence, abundance, and distribution of sulfonamide and tetracycline resistance genes in agricultural soils across China. Sci. Total Environ. 599-600, 1977-1983. doi: 10.1016/j. scitotenv.2017.05.152

Zinsstag, J., Schelling, E., Waltner-Toews, D., and Tanner, M. (2011). From "one medicine" to "one health" and systemic approaches to health and wellbeing. Prev. Vet. Med. 101, 148-156. doi: 10.1016/j.prevetmed.2010.07.003

Disclaimer: Any opinions, findings, and conclusions or recommendations expressed in this article are those of the authors and do not necessarily reflect the views of the National Science Foundation.

Conflict of Interest: The authors declare that the research was conducted in the absence of any commercial or financial relationships that could be construed as a potential conflict of interest.

Copyright (C) 2021 Fuhrmeister, Larson, Kleinschmit, Kirby, Pickering and BascomSlack. This is an open-access article distributed under the terms of the Creative Commons Attribution License (CC BY). The use, distribution or reproduction in other forums is permitted, provided the original author(s) and the copyright owner(s) are credited and that the original publication in this journal is cited, in accordance with accepted academic practice. No use, distribution or reproduction is permitted which does not comply with these terms. 